\title{
Vegetation Composition of Savanna Ecosystem as a Habitat For The Komodo Dragon (Varanus komodoensis) on Padar and Komodo Islands, Flores East Nusa Tenggara Indonesia
}

\author{
Sutomo ${ }^{1 *}$ \\ 1) Spatial Ecology Laboratory, Research Centre for Plant Conservation and Botanical Garden - Indonesian Institute of Sciences \\ (LIPI): Research Station Balai Konservasi Tumbuhan Kebun Raya Bali, Candikuning, Baturiti, Tabanan, Bali Indonesia 82191
}

Submitted: 29 July 2019; Accepted: 03 January 2020; Published: 15 April 2020

\begin{abstract}
Tropical savanna and dry forest in Indonesia are an important type of ecosystems that supports various endemic wildlife of Indonesia including savannas at Padar and Komodo Islands which is home to the Komodo ( $V$ aranus komodoensis). The Komodo dragon is considered as "Vulnerable" by the International Union for Conservation of Nature. Studies with regards to the Komodo dragons' habitats are scarce, considering that these types of habitats are significant to support Komodo's existence, but yet are also very prone to conversion and disturbances. This paper elaborates the results of ecological study on the tropical savanna forest in Komodo National Park as habitat for the Komodo dragon.Vegetation sampling was conducted using nested plots $20 \times 20 \mathrm{~m}, 10 \times 10 \mathrm{~m}, 5 \times 5 \mathrm{~m}$ and $2 \times 2 \mathrm{~m}$ spread across the sampling sites. Data was analysed using PRIMER software which includes cluster analysis, analysis of similarity (ANOSIM) and similarity percentage (SIMPER). As many as 17 plant species which belongs to 11 families were identified in the sampling sites. These consist of six trees habitus, six shrubs, four grasses and one palm. Asteraceae, Fabaceae and Poaceae were the plant families which has high number of species. The result of cluster analysis shows that the similarity level of the two groups (Komodo and Padar) based on the results of cluster analysis is $60 \%$. This result infers that there are similarities in terms of species composition in savanna on Komodo and Padar Island, however, each savanna still has its own species characteristics. This is confirmed by the ANOSIM test. The ANOSIM test results show the Global R value of 0.6.With the looming challenges from invasive alien plant species (IAPS), the Komodo Island's savanna has double threats to overcome. Hence conservation of the remaining savanna ecosystem is important.
\end{abstract}

Keywords: savanna, komodo, Padar, Flores, invasive alien plant species

\section{INTRODUCTION}

A range of ecosystem types and habitats that Indonesian archipelago has, created amazing species diversity and endemism. Nevertheless, swift and extensive habitat losses, together with the threatening challenge of climate change create a significant risk to the nation's biological diversity (Purwandana et al., 2014). Tropical savanna and dry forest in Indonesia are an important type of ecosystems that supports various endemic wildlife of Indonesia, some of which are under serious threat of extinction and have high conservation status according to IUCN categories, such as the wild Java

\section{*Corresponding author}

Email: tommo.murdoch@gmail.com

(C) 2020, J. Tropical Biodiversity Biotechnology (CC BY-SA 4.0)
Cattle (Bos javanicus) in the savanna of Baluran National Park in East Java, the endemic Bali Starling bird (Leucopsar rotschildi) in West Bali National Park savanna on Bali Island, and the Komodo Dragon (Varanus komodoensis) endemic only to Komodo Islands of East Nusa Tenggara. The Komodo dragon (Varanus komodoensisis) the world's largest lizard, of prominent conservation value as an umbrella species for protection of south-east Indonesian ecosystems (A. Ariefiandy et al., 2015).

Species with limited distribution or rapidly decreasing range margins are particularly sensitive to processes of global change (A. Ariefiandy et al., 2015; Davis et al., 2016). Given the high extinction risk facing such species, conservation program is likely to require multidisciplinary approaches that 


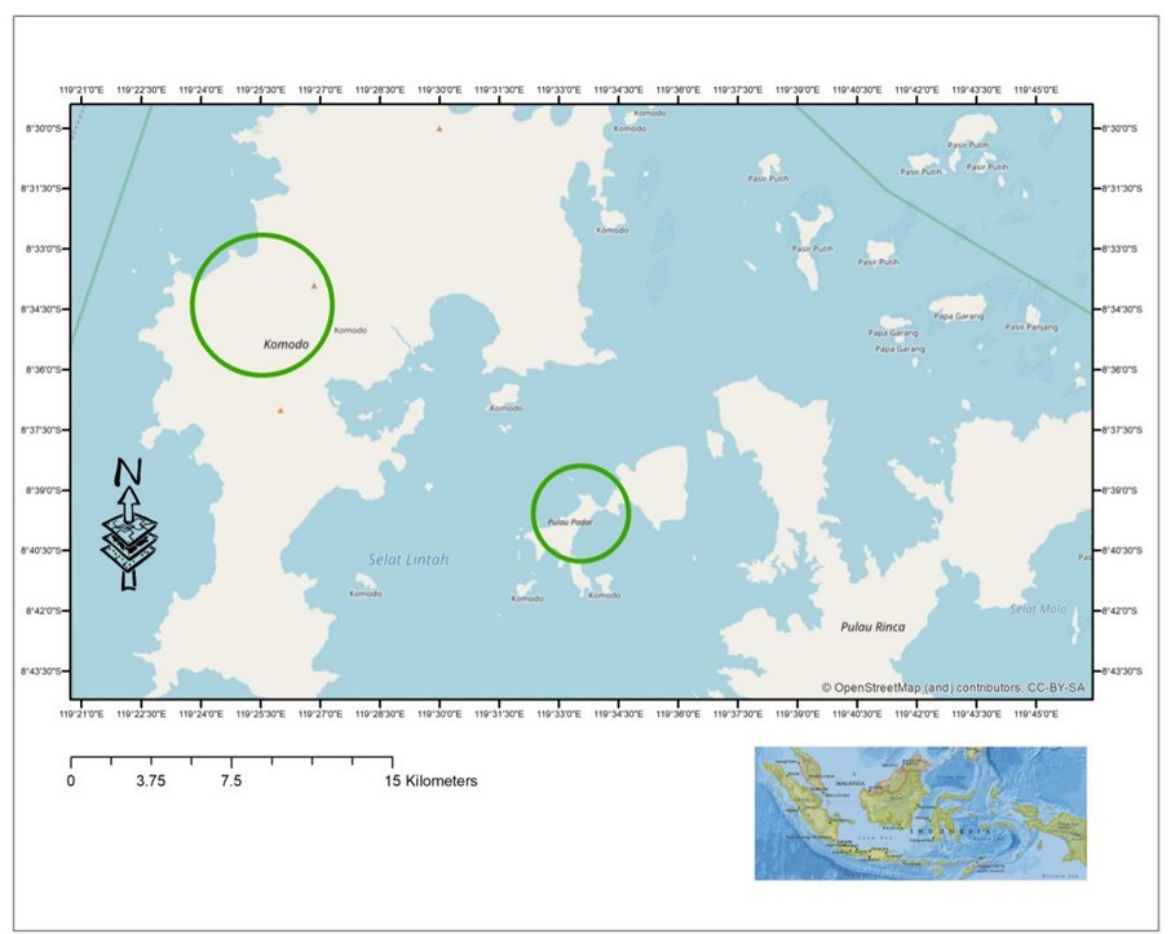

Figure 1. Location of the study in Komodo National Park, East Nusa Tenggara Province. Green circle point out Komodo and Padar Islands.

address both the species itself as well as their habitats (Estoque, Estoque, \& Murayama, 2012). The endemic Komodo dragon (Varanus komodoensisis) the world's largest lizard, with a highly restricted range distribution. The Komodo dragon is considered as "Vulnerable" by the International Union for Conservation of Nature (IUCN, 2014). Clearing of coastal dry monsoon forest, savanna Landuse change, anthropogenic fire regimes and competition with humans for prey species, such as Timor deer (Cervus timorensis florensis), are thought to be threatening processes influencing the viability of historically small dragon populations. Populations that are particularly at threat are those restricted to habitats on western Flores Island (Jessop et al., 2004).

There have been numerous studies on the Komodo dragon. Many of these studies have been focused on the Komodo dragon itself ranging from its behavior, genetic, ontogeny, nesting, and demography, among others (Auffenberg, 1981; CIOFI et al., 2011; Jessop et al., 2004; Purwandana et al., 2014; Purwandana et al., 2016). However, studies with regards to the Komodo dragons' habitats are scarce, considering that these types of habitats are significant to support Komodo's existence, but yet are also very prone to conversion and disturbances. This paper elaborates the results of ecological study on the tropical savanna forest in Komodo National Park as habitat for the Komodo dragon. The aim is to characterize savanna ecosystems in terms of their structure, diversity and composition. By studying its habitat, it is hoped that it could also aim to raise awareness on the importance of Komodo dragon habitat conservation alongside protection of the Komodo dragon itself.

\section{METHODS}

Nusa Tenggara is a group of small and mediumsized islands stretching from Lombok Island in the west, to Tanimbar Island in the east. East Nusa Tenggara consists of several islands, with the main ones being Flores, Komodo and Sumba. Sampling will concentrate on Padar and Komodo Islands. Komodo Island is where the dominant population of the dragon lies (Figure 1).

Field vegetation sampling was conducted in April 2018. Nested plots $20 \times 20$ m, $10 \times 10$ m, 5 x 5 $\mathrm{m}$ and $2 \times 2 \mathrm{~m}$ spread across the sampling sites to sample the vegetation (tree, poles, sapling and groundcovers) in savannas. In total there were ten nested plots. Plants were identifying the species and estimate the cover. Identification and plants material collection record conducted in the Herbarium Baliensis within the Eka Karya Botanical Garden - LIPI, as this botanical garden has an abundance of record collections from eastern parts of Indonesia, which is its specialty. Local environmental data for every plot also record, at a similar time of day (morning): soil $\mathrm{pH}$ and moisture; local microclimate (light intensity, air temperature, relative humidity, and wind velocity and heat stress index) and topography (altitude and slope). 
Table 1. Tabulation of plant species, families, and habitus on Padar and Komodo Islands.

\begin{tabular}{lllcc}
\hline \multicolumn{1}{c}{ Plant species } & \multicolumn{1}{c}{ Famili } & Habitus & Padar Island & Komodo Island \\
\hline Ageratina riparia & Asteraceae & Shrub & $\mathrm{x}$ & - \\
Alstonia sp & Apocynaceae & Tree & - & $\mathrm{x}$ \\
Anona muricata & Annonaceae & Tree & - & $\mathrm{x}$ \\
Chromolaena odorata & Asteraceae & Shrub & - & $\mathrm{x}$ \\
Coypha utan & Arecaceae & Palm & - & $\mathrm{x}$ \\
Crotalaria sp & Fabaceae & Shrub & $\mathrm{x}$ & - \\
Cymbopogon sp & Poaceae & Grass & $\mathrm{x}$ & - \\
Cyperus sp & Cyperaceae & Grass & $\mathrm{x}$ & - \\
Dysoxylum sp & Meliaceae & Tree & - & $\mathrm{x}$ \\
Glirisedia sepium & Fabaceae & Shrub & $\mathrm{x}$ & - \\
Hibiscus sp & Malvaceae & Shrub & $\mathrm{x}$ & - \\
Imperata cylindrica & Poaceae & Grass & - & $\mathrm{x}$ \\
Spondias dulcis & Anacardiaceae & Tree & - & $\mathrm{x}$ \\
Tamarindus indicus & Fabaceae & Tree & - & $\mathrm{x}$ \\
Themeda arguens & Poaceae & Grass & $\mathrm{x}$ & $\mathrm{x}$ \\
Tridaxprocumbens & Asteraceae & Shrub & $\mathrm{x}$ & - \\
Zisyphus jujube & Rhamnaceae & Tree & $\mathrm{x}$ & $\mathrm{x}$ \\
\hline
\end{tabular}

$\mathrm{X}$ sign means it was presence.

Cover data was used to test the differences in plant community composition between savannas. The data square-root transformed prior to constructing a resemblance matrix based on BrayCurtis similarity (Valessini 2009). A cluster ordination diagram then generated based on the resemblance matrix. The result of the cluster ordination was tested for significance using one-way ANOSIM (analysis of similarity). SIMPER (Similarity Percentage) analysis then used to explore the relative contribution of individual species to dissimilarity among savannas. This multivariate analysis makes use of the PRIMER V.6 package (Clarke \& Gorley, 2005). Correlations between floristic and local environmental gradients were explored using BEST (Bio-Env) module in PRIMER V.6.

\section{RESULTS AND DISCUSSION}

According to Purwandana et al.(2014), there are four main vegetation communities in Komodo National Park. Tropical monsoon forest dominates areas above 500-700 m. At lower elevations deciduous dry monsoon forest occurs in valley floors. Savanna woodland and savanna grassland occupy drier areas of the islands, although. perhaps what Purwandana et al.(2014) meant is that savanna woodlands are true savanna, whereas what they meant by savanna grasslands is a true grassland. Komodo dragon utilizes both dry monsoon forests and savannas in the Komodo National Park KNP). Komodo dragons preferentially use deciduous monsoon forest and savanna, as a consequence of their thermoregulatory requirements and the location of their prey (Achmad Ariefiandy et al., 2014).

In this study, the tropical savanna plant communities of the Padar and Komodo Islands in Flores East Nusa Tenggara have been characterized. As many as 17 plant species which belongs to 11 families were identified in the sampling sites (savannas in Padar and Komodo Islands). These consist of six trees habitus, six shrubs, four grasses and one palm (Table 1). Asteraceae, Fabaceae and Poaceae were the plant families which has a high number of species compared to other families (Figure 2). These numbers are quite high when we compare to the number of plant species and families found in the western and wetter parts of Indonesia such as savanna in Baluran and Alas Purwo (in East Java), Bali Barat (Bali) and Rinjani (Lombok). Sutomo (2017) found as many as 43 plant species within 26 families across the four savannas including one fern, seven grass or grass-like plants and two forbs.

However, there seems to be a separation between the two groups (Komodo and Padar). This result infers that there are similarities in terms of species composition in savanna on Komodo and Padar Island, however, each savanna still has its own species characteristics. This is confirmed by the ANOSIM test. The ANOSIM test results show the Global $\mathrm{R}$ value of 0.6. In Padar Island, the tree layer 


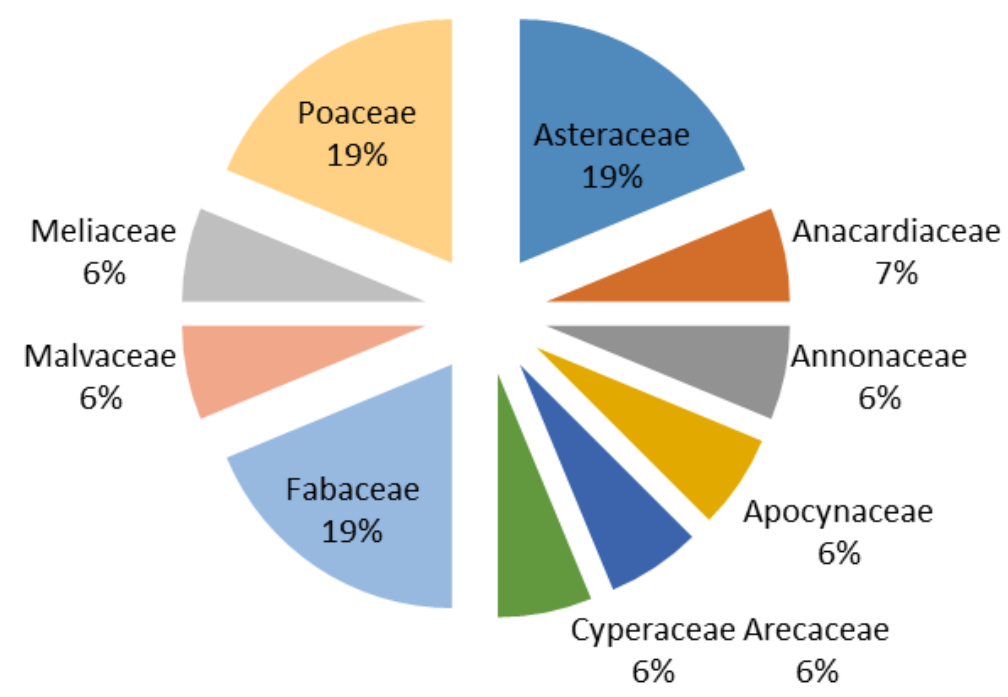

Figure 2. The Proportion of number of species each family has on Savannas in Padar and Komodo Islands.

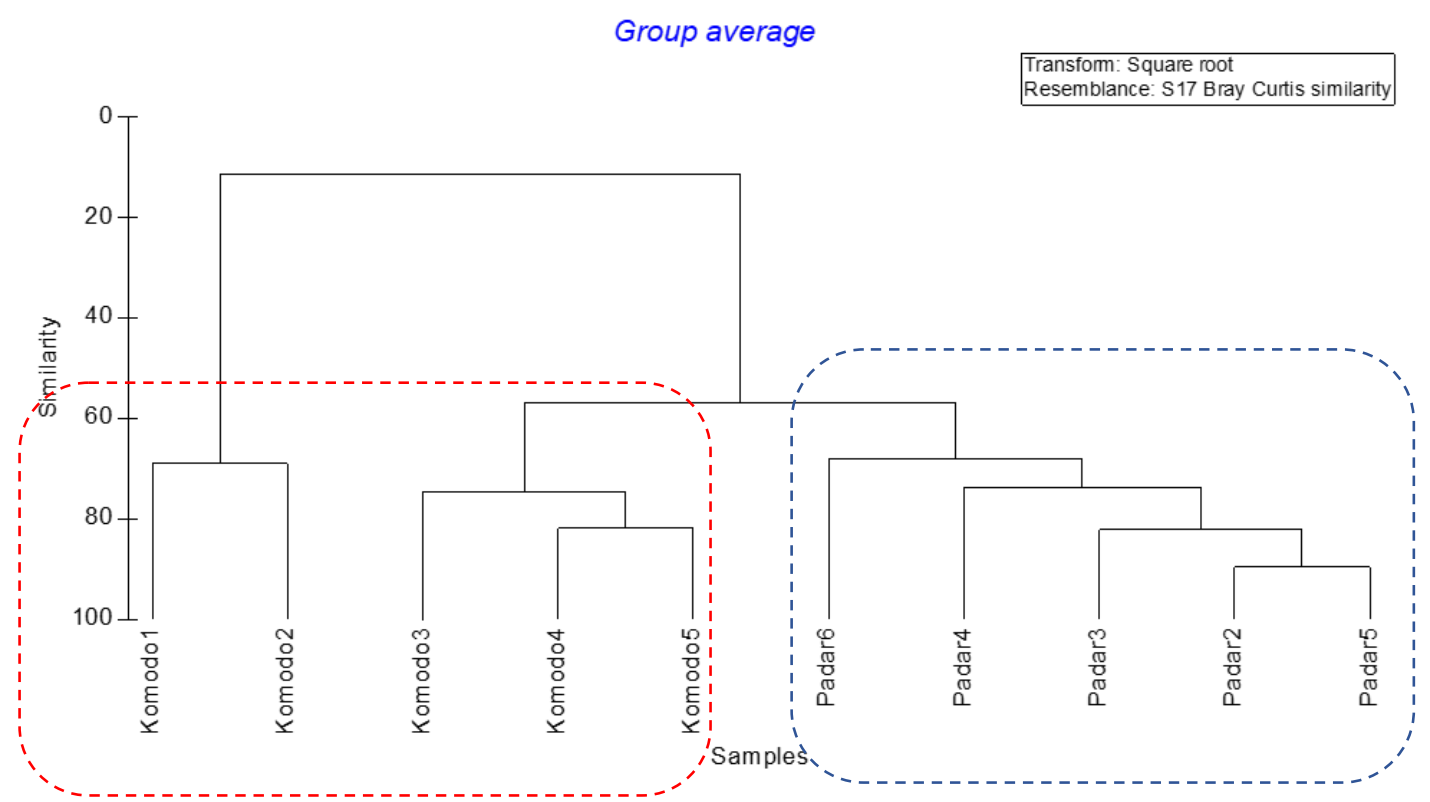

Figure 3. Result of Cluster analysis based on species composition data on Padar and Komodo Islands. $\mathrm{R}_{\mathrm{ANO} I \mathrm{M}}=0.6$

is occupied by Ziryphus jujuba, the groundcover was compose of grasses such as Cymbopogon, Cyperus and Themedea arguens, whereas the shrub layer were occupied by Crotalaria, Glirisedia, Hibiscus, Tridax procumbens and also the invasive alien species Ageratina riparia (Eupatorium riparium) (Table 1). Ziriphus is also the dominant tree species in Savanna in Baluran East Java (Sutomo \& van Etten, 2016). At Komodo Island, the tree layer is of Anona muricata, Dysoxylum sp, Spondias dulcis, Tamarindus indicus and also Zizyphus jujuba (Table 1). The grass layer on Komodo was from Themedea arguens and Imperata cylindrica species, whereas the shrub layer is occupied by invasive alien species Chromolaena odorata (Eupatorium odoratum) or known as "Kriyuh". The savanna on Komodo also has palm species (Coryphautan) (Table 1).
Asteraceae, Fabaceae and Poaceae were the plant families which has a high number of species compared to other families (Figure 2). This numbers are quite high when we compare to the number of plant species and families found in the western and wetter parts of Indonesia such as savanna in Baluran and Alas Purwo (in East Java), Bali Barat (Bali) and Rinjani (Lombok). Sutomo (2017) found as many as 43 plant species within 26 families across the four savannas including one fern, seven grass or grass-like plants and two forbs.

The results of cluster analysis using savanna vegetation data on both islands in the Komodo National Park show that the similarity level of the two groups (Komodo and Padar) based on the results of cluster analysis is 60\% (Figure 3).

In Padar Island, Themeda arguens grass and 
Table 2. Important species in each savanna at Padar and Komodo Islands as analyzed by SIMPER. Av.Abund = Average abundance; Av.Sim = Average similarity; Sim/SD refers to consistency; Contrib $\%=$ Percentage of contribution; Cum $\%=$ Cumulative percentage

\begin{tabular}{lccccl}
\hline \multicolumn{7}{c}{ Pulau Padar } \\
\hline Species & Av.Abund & Av.Sim & Sim/SD & Contrib\% & Cum.\% \\
Themeda arguens & 14.36 & 54.09 & 11.89 & 72.39 & 72.39 \\
Crotalaria sp & 5.57 & 18.51 & 2.39 & 24.78 & 97.16 \\
\hline \multicolumn{7}{c}{ Pulau Komodo } \\
\hline Species & Av.Abund & Av.Sim & Sim/SD & Contrib\% & Cum.\% \\
Chromolaena odorata & 6.62 & 23.35 & 3.05 & 49.76 & 49.76 \\
Themeda arguens & 10.15 & 16.84 & 0.62 & 35.90 & 85.66 \\
Imperata ylindrica & 2.54 & 2.53 & 0.32 & 5.39 & 91.05 \\
\hline
\end{tabular}

Crotalaria shrub plays an important contribution in the species composition configuration with $72.39 \%$ and $24.78 \%$ contribution respectively (Table 2 ).

In Komodo Island, Themeda arguens grass position was replaced by the IAS Chromolaena odorata with $49.76 \%$ contribution, whereas Themeda $35.90 \%$ and Imperata cylindrica grass $5.39 \%$. Imperata cylindrica is categorized as native invasive species. SIMPER analysis showed that eight species were mostly responsible for the dissimilarity between the two sites, Padar and Komodo (Table3). Themeda arguens appear in both islands but with different abundance. Themeda is abundant at Padar compare than Komodo. This perhaps due to the appearance of other grass species such as the native invasive Imperata cylindrica and also perhaps due to the competition with the alien invasive shrubs Chromolaena odorata (Table 3). The tree layer in Padar is characterized by the Bekul or Zizyphus whereas on Komodo it is the tamarind (Tamarindus indicus) (Table 3).

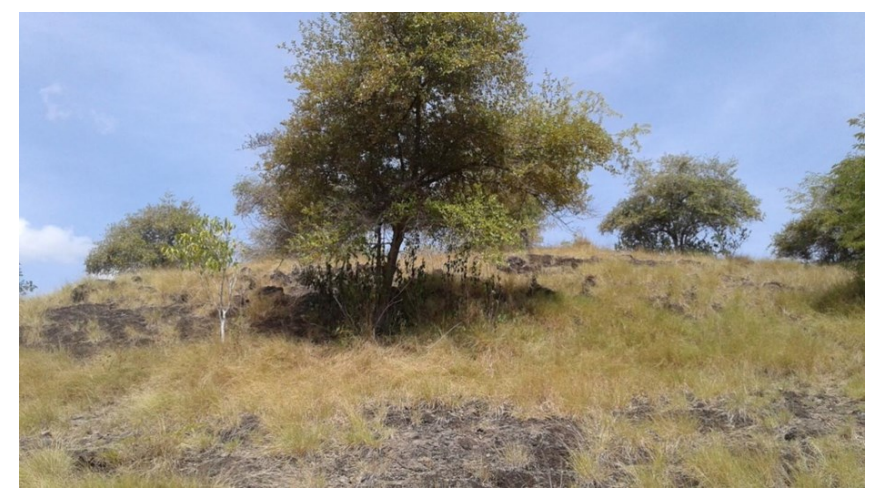

Figure 4. Bekul (Zizyphus jujuba). Zizyphus is one of a well -known tree species that characterized savanna vegetation.

As a comparison, in Baluran National Park in East Java, the Bekol Savanna, the dominant grass layer is the groundcover layer, which characterized by two grasses Polytrias indica and Dichanthium caricosum (Sutomo, 2017), whereas the Pangandaran savanna in West Java, the groundcover layer is of the characteristic of the secondary succession toward forest habitus, which Eleusine indica grass and the low creeping grasses Ischaemum rugosum dominates (Rosleine \& Suzuki, 2013).

The presence of invasive alien species is notable in most of the savannas. Similar problems also occur in other savannas such as savanna in West Bali with the Chromolaena odorata and Baluran with the Acacia nilotica (Caesariantika, Kondo, \& Nakagoshi, 2011; Sutomo, 2017). Caesariantika noted that the invasion of Acacia nilotica in Baluran NP has decreased its native/local species diversity. Shannon-Wiener species diversity index in Padar's (0.57) savanna is lower than Komodo's (0.699) savanna (Figure 5).

Table 3. Average of Pulau Padar and Pulau Komodo Groups

\begin{tabular}{lll}
\hline & $\begin{array}{l}\text { Group Pulau } \\
\text { Padar } \\
\text { Av. Abund. }\end{array}$ & $\begin{array}{l}\text { Group Pulau } \\
\text { Komodo } \\
\text { Av. Abund. }\end{array}$ \\
\hline Themeda arguens & 14.36 & 10.15 \\
Chromolaena odorata & 0.00 & 6.62 \\
Crotalaria sp & 5.57 & 0.00 \\
Imperata cylindrica & 0.00 & 2.54 \\
Glirisedia sepium & 1.20 & 0.00 \\
Zizpphus jujuba & 1.13 & 0.93 \\
Alstonia sp & 0.00 & 1.00 \\
Tamarindus indicus & 0.00 & 1.09 \\
\hline
\end{tabular}

dissimilarity $=65.24$

This phenomenon is perhaps due to several factors as described by Hill (2011). The Komodo Island has more types of ecosystems than Padar. Thus the recruitment of seasonally dry tropical forest (SDTF) species on Komodo's islands to the savannas is possible hence the species add to the Komodo's savannas species pool. This is the possible explanation, in the results section we can see that other tree species which are uncommon for 
savanna tree layer exist on the Komodo Island savanna such as Alstonia scholaris, Annona muricata, Dysoxylum sp and Spondias dulcis. In contrast, the Padar Island only has savanna as its ecosystem type, and the water body that divides the two islands create a barrier for recruitments from the SDTF on Komodo Island.

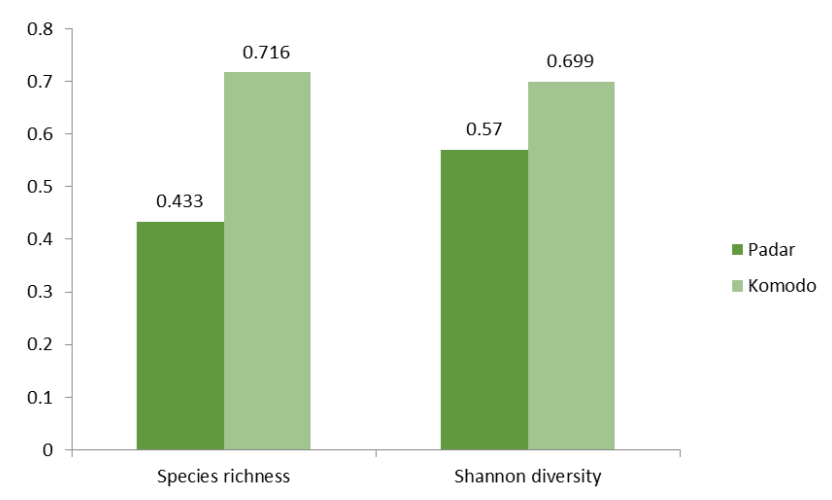

Figure 5. Shanon-Wiener species diversity index for Padar and Komodo Islands's savanna.

The consequence of the phenomenon on Komodo Island's various ecosystems types is that there is a possibility that the savanna might convert and transition to a STDF. This phenomenon has been observed in Baluran Savanna as reported by Sutomo \& van Etten (2016). This might not be beneficial for the Komodo dragon as they use both ecosystems type for their habitat. With the looming challenges from IAS the Komodo Island's savanna has double threats to overcome. Hence conservation of the remaining savanna ecosystem is important.

\section{REFERENCES}

Ariefiandy, A., Purwandana, D., Natali, C., Imansyah, M. J., Surahman, M., Jessop, T. S., et al., 2015, Conservation of Komodo dragons Varanus komodoensis in the Wae Wuul nature reserve, Flores, Indonesia: a multidisciplinary approach, International Zoo Yearbook, 49(1), 6780.

Ariefiandy, A., Purwandana, D., Seno, A., Chrismiawati, M., Ciofi, C., \& Jessop, T.S., 2014, Evaluation of three field monitoringdensity estimation protocols and their relevance to Komodo dragon conservation, Biodiversity and Conservation, 23(10), 2473-2490.

Auffenberg, W., 1981, The behavioral ecology of the Komodo monitor, University Press of Florida.

Caesariantika, E., Kondo, T. \& Nakagoshi, N., 2011, Impact of Acacia nilotica (L.) Willd. ex Del invasion on plant species diversity in the Bekol Savanna, Baluran National Park, East Java, Indonesia, Tropics 20(2), 45-54.
Ciofi, C., Tzika, A.C., Natali, C., Watts, P.C., Sulandari, S., Zein, M.S.A., et al., 2011, Development of a multiplex PCR assay for fine-scale population genetic analysis of the Komodo monitor Varanus komodoensis based on 18 polymorphic microsatellite loci, Molecular Ecology Resources, 11, 550-556.

Clarke, K.R. \& Gorley, R.N., 2005, PRIMER: Plymouth Routines In Multivariate Ecological Research (Version 6.0), Plymouth: PRIMER-E Ltd.

Davis, R.A., Doherty, T.S., van Etten, E.J.B., Radford, J.Q., Holmes, F., Knuckey, C., et al., 2016, Conserving long unburnt vegetation is important for bird species, guilds and diversity, Biodiversity and Conservation, 1-14.

Estoque, R.C., Estoque, R.S., Murayama, Y., 2012, Prioritizing Areas for Rehabilitation by Monitoring Change in Barangay-Based Vegetation Cover, ISPRS International Journal of Geo-Information, 1, 46-68.

Hill, M.J. \& Hanan, N.P., 2011, Ecosystem Function in Savannas. New York: CRC Press.

IUCN, 2014, The IUCN Red List of Threatened Species, Retrieved 2/09/2016, 2016, http:// www.iucnredlist.org

Jessop, T.S., Sumner, J., Rudiharto, H., Purwandana, D., Imansyah, M.J. \& Phillips, J.A., 2004, Distribution, use and selection of nest type by Komodo Dragons, Biological Conservation, 117 (5), 463-470.

Purwandana, D., Ariefiandy, A., Imansyah, M.J., Rudiharto, H., Seno, A., Ciofi, C., et al., 2014, Demographic status of Komodo dragons populations in Komodo National Park, Biological Conservation, 171, 29-35.

Purwandana, D., Ariefiandy, A., Imansyah, M.J., Seno, A., Ciofi, C., Letnic, M., et al., 2016, Ecological allometries and niche use dynamics across Komodo dragon ontogeny, Science Natural, 103(27), 6-11.

Rosleine, D. \& Suzuki, E., 2013, Secondary sucession at abandoned grazing sites Pangandaran Nature Reserve West Java Indonesia, Tropics 21(3), 91-103.

Sutomo, 2017, Ecology of the Savanna Ecosystems in Indonesia, Unpublished $\mathrm{PhD}$ Thesis, Edith Cowan University, Perth.

Sutomo \& van Etten, E., 2016, Unfolding Structure of Lowland Seasonal Tropical Dry Forest and Transition of Savanna in Indonesia, Paper presented at the EcoSummit 2016. Ecological Sustainability: Engineering Change, http:// www.ecosummit2016.org/ 